\title{
探究公路工程管理中的问题与改善
}

李升

合阳县农村公路管理局

DOI: $10.18686 /$ bd.v1i9.837

[摘要] 公路工程管理主要包括施工准备、施工现场、施工成本管理、施工管理人员以及施工安全管理等方面。基于各种 因素的影响, 公路工程管理过程中仍然存在诸多问题, 基于此, 本文阐述了公路工程管理的必要性, 对公路工程管理存在的 主要问题及其改善措施进行了探讨分析。

[关键词] 公路工程管理; 必要性; 问题;改善措施

1 公路工程管理的必要性

公路工程管理具有复杂性、综合性、系统性等特征。在 公路工程建设过程中, 需要优化管理方案, 加强施工进度及 施工质量管理, 实现施工成本的有效性控制, 确保各部分施 工模块的组织及协调, 实现公路工程施工整体体系的健全。 受到实际施工环境的影响, 施工现场管理的难度系数比较 高, 这受到资金投人环节、材料使用环节、施工技术环节、施 工进度控制环节等的影响, 为了实现公路工程整体管理效 益的增强, 必须进行施工现场管理规范性的控制, 提升施工 方案的整体应用效益。

\section{2 公路工程管理存在的主要问题分析}

2.1 施工准备不充分问题。公路工程建设周期比较长, 施工规模比较大, 受到内外施工环境的影响, 其施工质量及 施工进度具备不稳定性的特点, 为了实现工程整体施工效 益的增强, 必须充分做好施工准备工作。但是在实际施工 中, 有些施工单位并没有进行施工现场及沿线情况的仔细 勘察工作, 导致公路工程施工问题的出现, 导致一系列停 工、返工等问题的出现, 不利于施工工期的有效控制, 导致 一系列施工质量问题的出现。
2.2 施工现场管理问题。公路工程施工现场的管理是决 定工程质量达标的根本因素, 普遍存在的问题有, 现场有时 没有领导进行监督, 工作人员工作懒散, 没有整体的指挥人 员, 工作人员分配的工作地点不久当, 工人在作业时不注重 个人的安全问题, 偷工减料的人员大有人在, 原材料的使用 非常的浪费, 没有建立完整的管理系统, 安全的防范性措施 没有建立完整, 不注重工程工期的问题。这些问题是导致工 程出现延期的危害性问题。

2.3 成本管理问题。公路工程的成本直接影响企业的经 济效益, 目前我国公路工程成本管理中存在以下问题: 首先 是人员成本。公路工程是一个系统的整体, 人员众多, 在实 际的公路工程中存在着冗员现象, 即一个工作岗位安排多 名员工, 造成了工作效率的下降与工程成本的上升。第二是 材料成本, 材料资源的不合理配置与浪费现象造成了材料 成本的上升。最后是由于安全管理中的漏洞造成了安全事 故的出现,最终造成了工程成本的提高。

2.4 公路工程管理中管理人员的构成问题。目前公路工 程管理人员一般属于行政管理人员, 在实际公路工程管理 中, 面对突发情况, 他们往往按照行政管理的套路机械地解 
决问题，不能根据公路工程的实际情况做到一切从实际出 发, 这种缺乏技术素养的管理人员会直接影响公路工程管 理的质量水平, 进而影响到公路工程的进展, 影响到企业的 经济效益。

2.5 施工安全管理问题分析。主要有: (1) 安全意识问 题。相关统计分析, 公路工程建设安全事故的原因主要是工 作人员违反正常施工操作导致的, 其主要由于施工人员综 合素质不高, 并且缺乏专业的知识培训和安全教育, 导致安 全意识薄弱。(2)安全管理制度问题。目前我国大部分施工 企业只推行了一部分的安全生产管理制度, 并且缺乏一支 专门的施工监管队伍, 造成施工作业过程中存在很多的安 全隐患, 甚至发生严重的安全责任事故, 给施工人员带来惨 重的生命威胁，同时也给企业带来不可忽视的财产损失。 (3)施工设备管理的安全问题。公路工程建设中的实际施工 现场, 置放相关机械设备的过程中, 工作人员知识胡乱堆积 起来, 很容易产生一些安全隐患问题。此外, 很多施工单位 在进行相关设备安置过程中, 没有按照实际的规定进行定 期的保养和维护, 这样也就导致了一些设备引发的带病作 业情况出现。(4)现场施工安全问题。基于各种因素的影响, 在很多公路工程建设中, 施工现场管理仍然存在诸多安全 隐患, 导致施工现场情况较为混乱。例如, 在实际的施工过 程中, 随处乱扔建筑垃圾, 安全防护不标准、不到位, 安全措 施不落实。

\section{3 公路工程管理问题的改善措施}

3.1 充分做好施工准备的相关工作。在公路工程施工 前, 需要做好施工场地环境、地质条件、水文条件等调查工 作, 确保公路工程顺利开展, 进行各种工程影响因素的分 析, 做好工程各个影响因素的勘探及调查工作, 进行相关调 查报告的编写,实现施工方案效益的增强。

并且为了提升公路建设的整体质量, 必须进行施工图 纸的反复性研究, 深人了解工程设计意图, 严格按照施工图 纸相关要求展开施工, 做好技术交底及业务培训工作。

3.2 建立健全相关管理制度。为了保障公路工程建设的 顺利实施, 必须健全完善相关管理制度。首先, 施工单位需 要完成一系列的管理制度,其中包括设备管理、检查监督、 员工绩效考核。其次, 施工单位需要和公路工程建设相关政 府机构联合, 进一步完善施工安全法律法规。另外, 施工队 伍需要严格遵守施工标准,进行正确的施工作业。

3.3 严格公路工程成本控制。公路工程管理中最重要的 一项控制就是成本控制, 笔者认为需要做好以下几点: (1) 完善成本管理制度, 使一切跟成本有关的行为都在其约束 范围之内, 其次成本管理制度要与时俱进, 根据变化的外部 以及内部环境来进行实时改进。(2)制定计划时要明确各小 组的施工定额, 然后根据定额来分配人力, 物力等各项资 源, 力求每一项都在成本预算的范围之内。(3)在阶段性成 果取得之后, 要及时地进行反馈, 对已使用的成本进行详细 的记录, 比较与之前计划的出人。并分析超出的原因以及补
救措施, 以及对今后阶段避免相同情况的建议。

3.4 加强人本管理。管理归根结底来说是对人的管理, 人员是任何管理中最基本的组成单位, 管理的核心也是要 调动人员的积极性和创作力。在公路工程项目施工管理中 激发每一个员工个人的积极性, 并且要积极引导他们的努 力方向,工作重心完全符合公路工程建设方向, 这就需要管 理者高超的管理艺术支撑。

3.5 加强公路工程安全管理。主要表现为: (1)提高从业 人员安全意识。首先, 施工企业在招聘员工时应该把安全意 识作为重点考查之一。其次, 工程项目管理人员需要按照要 求对于新员工进行三级安全教育培训, 定期开展相关的知 识强化的训练, 不断培养出相关操作人员的安全生产方面 的意识, 逐渐提升他们的专业技能以及实际性的操作技巧 和能力。另外, 公路工程建设作业属于高强度的体力劳动, 为保障安全, 施工单位应该科学安排施工人员作业和休息 时间, 让施工人员能够在长时间工作后进行足够的休息, 从 而避免因为过度工作劳累出现人身危险。(2)健全相关安全 管理制度。首先, 施工单位需要完成一系列的管理制度, 其 中包括设备管理、检查监督、员工绩效考核。其次,施工单位 需要和公路工程建设相关政府机构联合, 进一步完善施工 安全法律法规。另外, 施工队伍需要严格遵守施工标准, 进 行正确的施工作业。(3)严格施工设备安全管理。首先, 施工 项目组招聘员工需要进行专业的现场考核, 考查其设备规 范操作和安全意识。其次, 施工人员应该保证有合法的设备 操作证书。另外,施工企业需要要求施工人员对设备进行保 养和维护, 并实施一定的奖惩措施, 鼓励施工人员保障设备 的安全。这就要求施工企业有一套健全的机械设备使用维 护保养制度。(4)加强施工现场安全监督。施工现场安全监 督管理相关的工作内容关系到整个公路工程建设质量, 没 有好的质量的施工工程很难实际投人使用。因此加强对于 公路工程建设现场的监督过程是改善现场施工安全状况的 重要内容。因此需要安排专业的工作人员来进行安全机构 管理,明确相关工作人员的安全监督责任。

\section{4 结束语}

综上所述, 随着城镇化建设的不断推进以及交通运输 的快速发展, 使得公路工程建设不断增多, 为了提高公路工 程的经济效益以及保障公路工程质量, 必须加强公路工程 管理,并且必须对公路工程管理中存在的问题, 及时采取相 应的改善措施。

\section{参考文献:}

[1]王亚晖,曲信静.公路工程施工管理的问题及改善 措施[J].技术与市场,2012

[2]杨关键.道路桥梁施工技术与施工管理实践 [J].设 备管理与维修, 2017

[3]冯双雪.我国高速公路施工管理中存在的问题及解 决办法研究[J].交通世界,2017 